\title{
Comparative studies on enhanced oil recovery by alkali-surfactant and polymer flooding
}

\author{
Abhijit Samanta $\cdot$ Achinta Bera $\cdot$ Keka Ojha $\cdot$ \\ Ajay Mandal
}

Received: 9 December 2011 / Accepted: 19 March 2012/Published online: 6 June 2012

(c) The Author(s) 2012. This article is published with open access at Springerlink.com

\begin{abstract}
Chemical flooding methods are now getting importance in enhanced oil recovery to recover the trapped oil after conventional recovery. In the present study, a comprehensive study has been carried out on alkali, surfactant and polymer flooding. The chemicals with different compositions and combinations were used to recover the oil after conventional water flooding. It has been observed that increase in concentration of alkali, surfactant and polymer increases the additional recovery, but beyond a certain limit, the increase in recovery is only marginal. A series of flooding experiments using the combination of the above methods have been performed with additional recoveries more than $25 \%$. An analysis has been made on the relative cost of the different chemical slugs injected and the corresponding additional oil recovery. Based on the analysis, an optimum composition of the alkali-surfactant-polymer system has been recommended.
\end{abstract}

Keywords ASP flooding · Oil recovery · Viscosity · Surface tension

\section{Introduction}

In the recent years, a great progress has been made either in laboratory studies or in pilot tests for alkali/surfactant/ polymer (ASP) and surfactant/alkali/polymer (SAP) combination flooding (Zhang et al. 2007; Hou et al. 2005; Daoshan et al. 2004; Thomas and Farouq Ali 2001; Zerpa et al. 2005; Wang et al. 2011). ASP flooding is a technique

A. Samanta $\cdot$ A. Bera $\cdot$ K. Ojha $\cdot$ A. Mandal $(\bowtie)$

Enhanced Oil Recovery Laboratory, Department of Petroleum Engineering, Indian School of Mines, Dhanbad 826 004, India e-mail: mandal_ajay@hotmail.com which is developed out on the basis of alkali flooding, surfactant flooding and polymer flooding (Wang et al. 2007) and oil recovery is enhanced gently by decreasing interfacial tension (IFT), increasing capillary number, enhancing microscopic displacing efficiency, improving mobility ration and increasing macroscopic sweep efficiency (Shen and Yu 2002). Alkali forms soaps by reacting with naturally occurring organic acid in the crude oil, which interact synergistically with added surfactant to produce ultra-low IFT (Al-Sahhaf et al. 2002; Gao et al. 1995; Martin et al. 1995). The ultra-low IFT is obtained by surfactant distribution between oil and water phase, and surfactant arrangement at interface of oil/water. This is controlled by $\mathrm{pH}$ value and ionic strength (Rudin et al. 1994; Jun et al. 2000). The alkali injected with surfactant can reduce surfactant adsorption, play the role of ionic strength and lower IFT (Krumrine et al. 1982, 1983; Martin and Oxley 1985). Addition of polymer increases the viscosity of its aqueous phase (Walters and Jones 1989), so that the mobility of aqueous phase decreases. Thus, the decrease in mobility ratio greatly increase sweep efficiency. Another main accepted mechanism of mobile residual oil after water flooding is that there must be a rather large viscous force perpendicular to the oil-water interface to push the residual oil. This force must overcome the capillary forces retaining the residual oil, move it, mobilize it, and recover it (Guo and Huang 1990). Wang et al. (2010) studied the viscoelastic effect of retained polymer molecules in porous media based on the pressure draw-down and buildup process. They proposed that the micro-scale displacement efficiency depends on the flow pattern and magnitude of the viscous force parallel to the oil-water interface.

Under the same displacement efficiency as that of surfactant/polymer flooding, the ASP and SAP flooding 
reduce the concentration of surfactant by more than ten times, as well as the capital cost of the surfactant. Two pilot tests of ASP and SAP flooding have been successful in China. The one (SAP) is in Daqing Oil Field for waxy crude oil of low acid (Gao et al. 1996), and the other (ASP) is in Shengli Oil Field for the high acid oil (Song et al. 1995; Krumrine et al. 1983).

Substantial research works are being carried out worldwide on alkali, surfactant and polymer flooding by different researchers (Nasr-El-Din et al. 1994; Al-Hashim et al. 1996; Taylor and Nasr-El-Din 1996). Hawkins et al. (1994) reported that the simultaneous injection of alkali and polymer is more effective than the same chemicals injected sequentially with no contact between alkali and polymer. Tong et al. (1998) and Guo (1990) reported that the main mechanisms of ASP flooding are interface producing, bridging between inner-pore and outer-pore and oil-water emulsion. In a vertical heterogeneous reservoir, ASP flooding increases displacing efficiency by displacing residual oil through decreasing IFT and improving sweep efficiency. Wanchao et al. (1995) reported that ASP flooding is more effective for oil with high acid value. They showed that flooding system's rheology and IFT between flooding system and oil with high acid value were the key factors effecting oil recovery. Shen et al. (2009) investigated the fluid-flow mechanism of enhanced oil recovery (EOR) in porous media by ASP flooding. They have reported that ASP flooding displaces not only the residual oil in the high-permeability layer but also the remaining oil in the low- and middle permeability layers by increasing both swept volume and displacement efficiency.

A critical step for the optimal design and control of ASP recovery processes is to find the relative contributions of design variables such as, slug size and chemical concentrations, in the variability of given performance measures (e.g., net present value, cumulative oil recovery), considering a heterogeneous and multiphase petroleum reservoir. In the present work, comprehensive studies have been done on ASP flooding varying the concentration and composition of different chemicals.

\section{Experimental}

Materials

Anionic surfactant, sodium dodecyl sulfate (SDS) $\left(\mathrm{C}_{12} \mathrm{H}_{24} \mathrm{SO}_{4} \mathrm{Na}\right.$, MW $\left.=288.38\right)$ was purchased from Central Drug House (P) Ltd., India. Reagent-grade sodium hydroxide (96\% purity) from Sd Fine-Chem Ltd., was used as alkali. Partially hydrolyzed polyacrylamide (PHPAM) (Polymer Pusher 1000, SNF Floerger, France) is used as polymer. The crude oil used in the flooding experiments was collected from Ahmedabad Oil Field (India). It was degassed and dehydrated, with a viscosity of $50.12 \mathrm{mPa} \mathrm{s}$ at $45^{\circ} \mathrm{C}$, and a total acid number of $0.038 \mathrm{mg} \mathrm{KOH} / \mathrm{g}$.

Experimental apparatus and methods

The experimental apparatus is composed of a sand-pack holder, cylinders for chemical slugs and crude oil, positive displacement pump, measuring cylinders for collecting the samples. The detail of the apparatus is shown in Fig. 1. The displacement pump is one set of Teledyne Isco syringe pump. Control and measuring system is composed of different pressure transducers and a computer. The physical model is homogeneous sand-packing model vertically positive rhythm. The model geometry size is $L=35 \mathrm{~cm}$ and $r=3.5 \mathrm{~cm}$.

Sandpack flood tests were employed for the evaluation of the effectiveness of ASP flooding. For uniform sandpacks, 60-100 mesh sand was poured into the coreholder which was vertically mounted on a vibrator and filled with $1.0 \mathrm{wt} \%$ brine. The coreholder was fully filled at a time and was vibrated for one hour. The wet-packed sandpack was flooded with the heavy oil until water production ceased (water cut was less than $1 \%$ ). The initial water saturation was determined on the basis of mass balance. The wetpacked sandpack was flooded with the crude oil at 800 psig to irreducible water saturation. The initial water saturation was determined on the basis of mass balance. Water flooding was conducted horizontally at a constant injection flow rate. The same injection flow rate was used for all the displacement tests of this study. After water flooding, $\sim 0.5 \mathrm{PV}$ alkali (for alkali flooding) polymer slug (for polymer flooding) and surfactant (for surfactant flooding) were injected followed by $\sim 2.0 \mathrm{PV}$ water injection as chase water flooding. The same methods are followed for different combinations alkali, surfactant and polymer floodings.

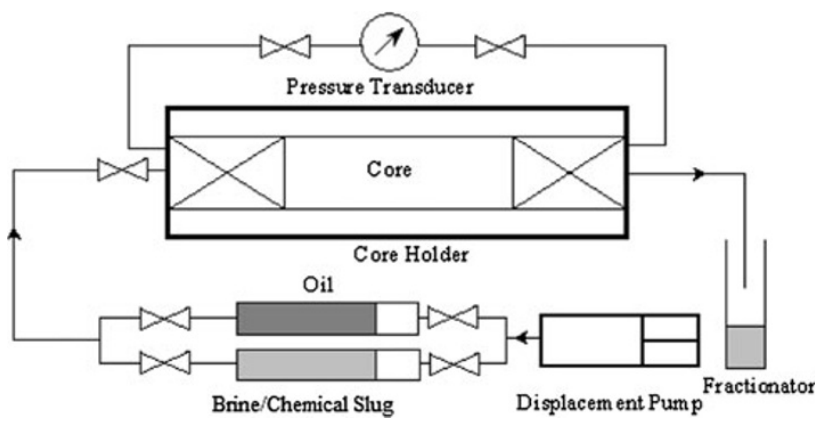

Fig. 1 Schematic of experimental set-up for polymer flooding in sandpacks 


\section{Results and discussion}

Effect of alkali and polymer on surface tension of surfactant solutions

The variations of surface tension with the surfactant concentration in the presence of polymer and alkali have been presented in Fig. 2. The ability to lower the surface tension between aqueous solutions and other phases is one of the most significant aspects of surfactants that raise their applicability in industries. The critical micelle concentration (CMC), one of the main parameters for surfactants, is the concentration at which the surfactant solutions begin to form micelles in large amount (Hoff et al. 2001). Presence of polymer and alkali in a solution of surfactant significantly influences the surface tensions (Nedjhioui et al. 2005; Horváth-Szabó et al. (2002). For evaluating the effect of polymer on the surface properties, surface tension measurements of SDS surfactants have been performed in the presence and absence of polymer. From Fig. 2, it may be seen that polymer increases the surface tension of the surfactant solution due to interaction of the functional group of both polymer and ionic surfactant (Minatti and Zanette 1996; Suksamranchit and Sirivat 2007). On the other hand, addition of alkali reduces the surface tension as alkali itself reduces the surface tension of water significantly (Nedjhioui et al. 2005; Horváth-Szabó et al. 2002).

Effect of alkali and surfactant on the viscosity of polymer solutions

The effects of interactions between alkali and surfactant with polymer viscosity must be considered while injecting such ASP slug for EOR. Alkali can modify the viscosity of a

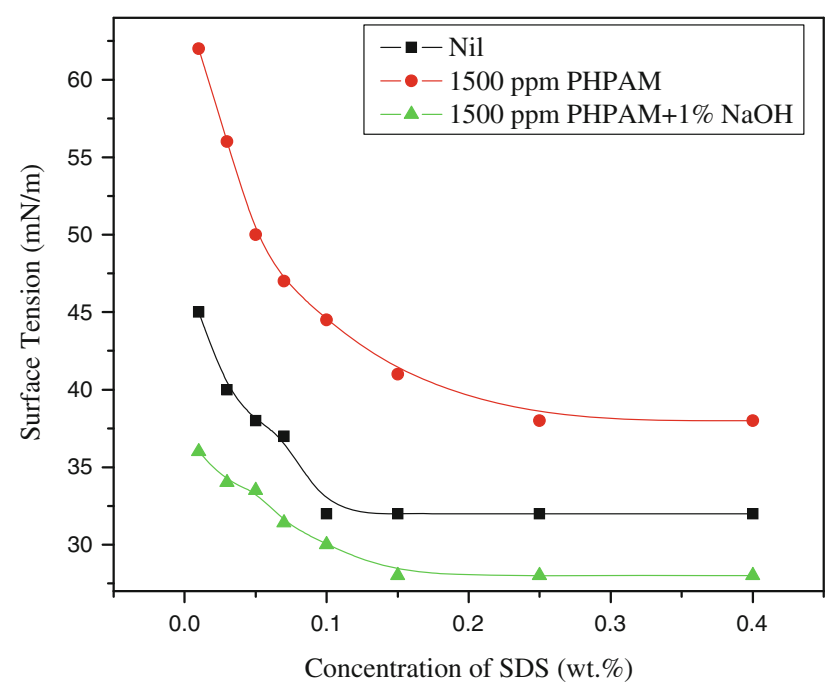

Fig. 2 Effect of alkali on surface tension of in the presence of polyacrylamide
PHPAM solution in two ways; first, alkali provides cations into the polymer solution. These cations can reduce polymer viscosity (Fig. 3) through the charge shielding mechanism (Guo et al. 1998; Samanta et al. 2011) Second, alkali can hydrolyze the amide groups on the polymer chain (base hydrolysis). This process can increase the polymer solution viscosity. Obviously, the net effect of alkali on the polymer solution viscosity depends on the relative extent of these two factors. Surfactant slugs are frequently used in EOR processes to mobilize residual oil by changing rock wettability or reducing IFT. To increase the efficiency of such processes, polymers can be co-injected with the surfactant slug. Under the reservoir condition, the surfactant can be mixed with polymer which leads to change of viscosity of the polymer solution. It is very important to simulate the viscosity of polymer solutions or mobility ratio for any ASP injection process. Thus, the effects of SDS on the viscosity of PHPAM solutions were examined. Figure 3 also shows the effect of SDS concentration on the apparent viscosity of PHPAM polymer solution having $1,000 \mathrm{ppm}$. The apparent viscosity of polymer decreases in the presence of surfactant. These results indicate that SDS reacts physically as well as chemically with the polymer chain in deionized water. This trend is similar to that observed by (Shupe 1981) and it was suggested that anionic surfactant affects the viscosity behavior of polyacrylamide through charge-shielding mechanism, which causes the shrinkage of molecular chains of polymer and the decrease of hydrodynamic radius.

Comparison of alkali, surfactant, polymer, surfactant polymer and alkali-surfactant-polymer flooding for EOR

The additional oil recovery by alkali injection after conventional water flooding is obtained by four possible

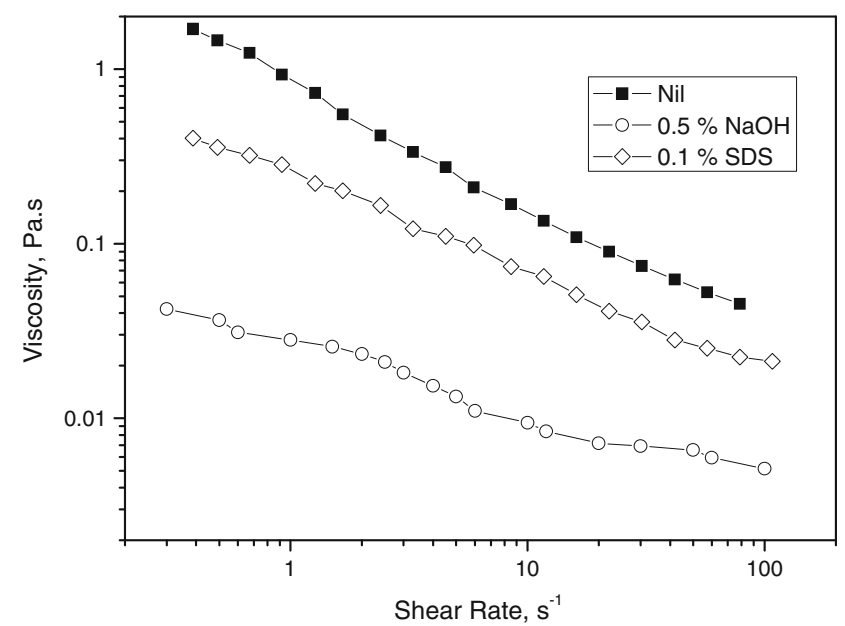

Fig. 3 Effect of $\mathrm{NaOH}$ and SDS on viscosity of 1,000 ppm PHPAM solutions 
mechanisms (Johnson 1976) viz., reduction of oil-water IFT; in situ formation of surfactant by reacting with acidic components of oil; emulsification of oil into water; wettability alteration and improvement of sweep efficiency by emulsification and entrapment. $\mathrm{NaOH}$ is conventionally used as alkali as it is relatively cheaper and reduces the surface tension or IFT between oil and water significantly. Our earlier work (Khan et al. 2009) reported that surface tension of $\mathrm{NaOH}$ in its aqueous solution decreases as its concentration increased up to $1 \%$ and then remains almost constant. Thus, in the present study, concentrations of $\mathrm{NaOH}$ were varied from 0.5 to $1.0 \%$ for flooding experiments. The additional oil recovery after conventional water flooding has been shown graphically in Fig. 4. The additional recovery is around $14 \%$.

Polymers are often used as mobility controller for EOR. Injection of small quantity of polymer significantly increases the viscosity of solution, which can increase the sweep efficiency of the displacing fluid in the porous media during flooding. The aqueous solution of polymer shows non-

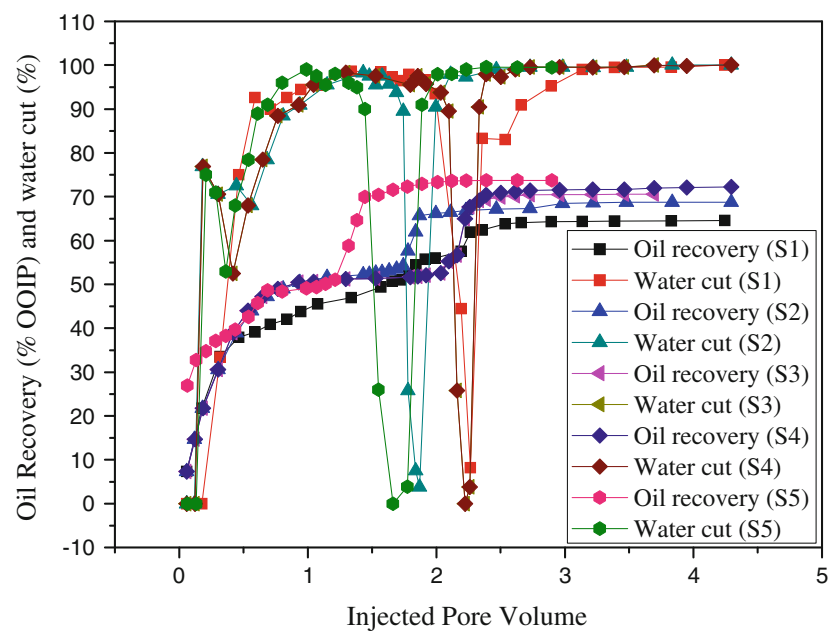

Fig. 4 Cumulative oil recovery and water cut using alkali, surfactant, polymer, surfactant polymer and alkali-surfactant-polymer slug
Newtonian behavior and its apparent viscosity is function of polymer concentration, shear rate, temperature, etc. (NasrEl-Din et al. 1992). For economic implementation of polymer flooding projects, concentration of different polymer is generally varied from 1,000 to $2,000 \mathrm{ppm}$ (Needham and Doe 1987), and hence, the polymer concentration for this present study was kept in the aforesaid range. The additional oil recovery by injection of 0.5 PV $1,500 \mathrm{ppm}$ PHPAM followed by chase water is around $16 \%$ after conventional water flooding has been shown in Fig. 2.

Surfactants are considered as good EOR agents since 1970s (Healy and Reed 1974), because, it can significantly lower the IFTs and alter wetting properties. Displacement by surfactant solutions is one of the important tertiary recovery processes by chemical solutions. The addition of surfactant decreases the IFT between crude oil and formation water, lowers the capillary forces, facilitates oil mobilization, and enhances oil recovery. The concentrations of surfactants are generally kept above their CMC. SDS was used as surfactant for the present study and its concentration was varied from 0.1 to $0.3 \%$. The typical additional recovery using surfactant after water flooding is shown in Fig. 4.

The comparative picture of additional recovery of individual alkali, polymer and surfactant under economic limit is shown in Table 1. It has been found that the injection of same pore volume of combined surfactant and polymer gives better recovery than either of the above methods. This is because of reduced IFT using surfactant and improved mobility by polymer. The oil recovery and corresponding water cut are shown in Fig. 4. The synergistic effects of alkali, surfactant and polymer in ASP flooding again gives higher recovery compare to others.

\section{Effect of polymer in ASP flooding}

Figure 5 shows a typical ASP flooding for EOR after water flooding where concentration of alkali and surfactant are kept constant. Significant additional recovery after water

Table 1 Comparison of Alkali, surfactant, polymer, surfactant polymer and alkali-surfactant-polymer flooding for enhanced oil recovery

\begin{tabular}{|c|c|c|c|c|c|c|c|c|c|}
\hline \multirow[t]{2}{*}{$\begin{array}{l}\text { Expt. } \\
\text { No. }\end{array}$} & \multirow[t]{2}{*}{$\begin{array}{l}\text { Porosity } \\
(\%)\end{array}$} & \multicolumn{2}{|c|}{$\begin{array}{l}\text { Permeability, } \\
k \text { (darcy) }\end{array}$} & \multirow[t]{2}{*}{ Design of chemical slug for flooding } & \multirow{2}{*}{$\begin{array}{l}\text { Recovery of oil } \\
\text { by water flooding } \\
\text { at } 95 \% \text { water cut } \\
\text { (\% OOIP) }\end{array}$} & \multirow{2}{*}{$\begin{array}{l}\text { Additional } \\
\text { recovery } \\
(\% \text { OOIP })\end{array}$} & \multicolumn{3}{|c|}{ Saturation $(\%)$} \\
\hline & & $\begin{array}{l}k_{\mathrm{w}} \\
\left(S_{\mathrm{w}}=1\right)\end{array}$ & $\begin{array}{l}k_{\mathrm{o}} \\
\left(S_{\mathrm{wi}}\right)\end{array}$ & & & & $S_{\mathrm{wi}}$ & $S_{\mathrm{oi}}$ & $S_{\text {or }}$ \\
\hline $\mathrm{S} 1$ & 38.665 & & & $0.5 \mathrm{PV} \mathrm{NaOH}(0.5 \%)+$ chase water & 50.71 & 13.88 & 19.1 & 80.9 & 25.4 \\
\hline $\mathrm{S} 2$ & 37.265 & 1.235 & 0.218 & 0.5 PV 1,500 ppm PHPAM + chase water & 52.65 & 16.12 & 18.51 & 81.49 & 22.96 \\
\hline S3 & 38.665 & 1.234 & 0.212 & 0.5 PV SDS $(0.1 \%)+$ chase water & 51.65 & 17.96 & 19.09 & 80.91 & 20.2 \\
\hline S4 & 36.805 & 1.224 & 0.213 & $\begin{array}{l}0.3 \text { PV } 0.1 \% \text { SDS + } 0.2 \text { PV } 2,000 \mathrm{ppm} \\
\text { PHPAM + chase water }\end{array}$ & 51.35 & 20.99 & 15.00 & 85.00 & 22.87 \\
\hline S5 & 37.265 & 1.144 & 0.217 & $\begin{array}{l}0.3 \mathrm{PV}(0.5 \% \mathrm{NaOH}+0.1 \% \mathrm{SDS}+1,500 \mathrm{ppm} \\
\text { PHPAM })+0.2 \mathrm{PV} 1,500 \mathrm{ppm} \text { buffer }+ \text { chase } \\
\text { water }\end{array}$ & 50.20 & 23.69 & 18.52 & 81.48 & 20.49 \\
\hline
\end{tabular}


flooding was observed by injection of 0.3 PV ASP slug and $0.2 \mathrm{PV}$ polymer followed by chase water. It may be seen from Table 2 that additional recovery increases only

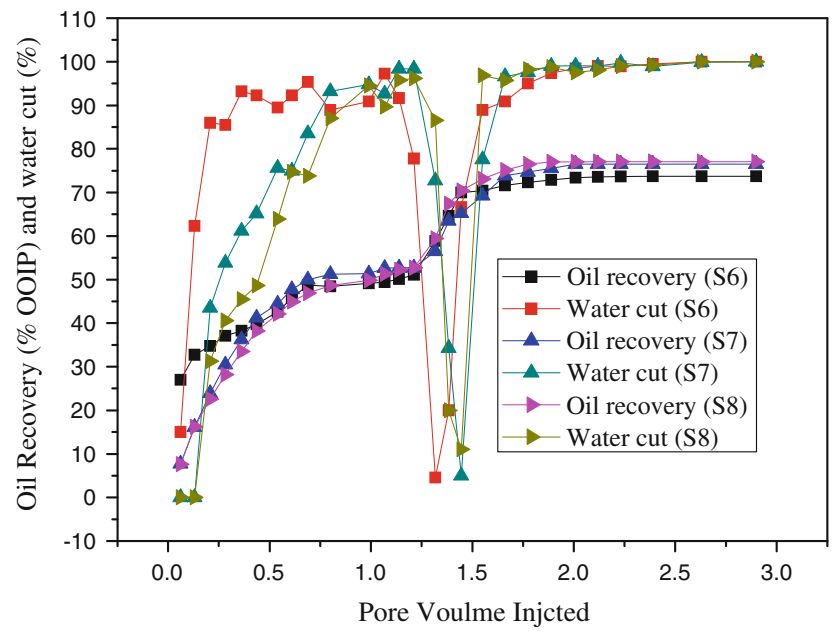

Fig. 5 Production performance of alkali-surfactant-polymer flooding (where $1 \%$ SDS and $0.5 \mathrm{wt} \% \mathrm{NaOH}$ used) marginally as concentration of PHPAM is changed from 1,500 to $2,500 \mathrm{ppm}$. Injection of polymer increases the sweep efficiency, and hence, oil recovery. After a certain concentration of polymer, the sweep efficiency approaches to its limiting value and thus only marginal additional recovery is observed.

Effect of alkali in ASP flooding

Table 3 summarizes the three sets of ASP flooding experiments where same pore volumes of different chemical slugs were used. The effects of alkali have been studies by varying the concentrations of alkali in the ASP slug. An increase in concentration of alkali increases the additional recovery as it is well known that the injected alkali quickly reacts with the carboxylic acid groups of crude oil forming in situ surfactant. Presence of alkali in a solution significantly influences the surface and IFTs. Significantly lower values of surface tension are observed in alkali-polymersurfactant system due to synergistic effect of surfactant and alkali compared to surfactant-polymer system without

Table 2 Recovery of oil by ASP flooding with varying concentration of polymer

\begin{tabular}{|c|c|c|c|c|c|c|c|c|c|}
\hline \multirow[t]{2}{*}{$\begin{array}{l}\text { Expt. } \\
\text { No. }\end{array}$} & \multirow[t]{2}{*}{$\begin{array}{l}\text { Porosity } \\
(\%)\end{array}$} & \multicolumn{2}{|c|}{$\begin{array}{l}\text { Permeability, } \\
k \text { (darcy) }\end{array}$} & \multirow[t]{2}{*}{ Design of chemical slug for flooding } & \multirow{2}{*}{$\begin{array}{l}\text { Recovery of oil after } \\
\text { water flooding at } 95 \% \\
\text { water cut }(\% \text { OOIP) }\end{array}$} & \multirow{2}{*}{$\begin{array}{l}\text { Additional } \\
\text { recovery } \\
(\% \text { OOIP })\end{array}$} & \multicolumn{3}{|c|}{ Saturation $(\%)$} \\
\hline & & $\begin{array}{l}k_{\mathrm{w}} \\
\left(S_{\mathrm{w}}=1\right)\end{array}$ & $\begin{array}{l}k_{\mathrm{o}} \\
\left(S_{\mathrm{wi}}\right)\end{array}$ & & & & $S_{\mathrm{wi}}$ & $S_{\mathrm{oi}}$ & $S_{\text {or }}$ \\
\hline S6 & 37.265 & 1.144 & 0.217 & $\begin{array}{l}0.3 \mathrm{PV}(0.5 \% \mathrm{NaOH}+0.1 \% \\
\mathrm{SDS}+1,500 \mathrm{ppm} \text { PHPAM })+0.2 \mathrm{PV} \\
1,500 \mathrm{ppm} \text { buffer }+ \text { chase water }\end{array}$ & 50.2 & 23.69 & 18.519 & 81.482 & 20.49 \\
\hline S7 & 36.805 & 1.145 & 0.218 & $\begin{array}{l}0.3 \mathrm{PV}(0.5 \% \mathrm{NaOH}+0.1 \% \\
\mathrm{SDS}+2,000 \mathrm{ppm} \text { PHPAM })+0.2 \mathrm{PV} \\
2,000 \text { ppm buffer }+ \text { chase water }\end{array}$ & 52.8 & 23.5 & 17.500 & 82.500 & 20.45 \\
\hline S8 & 37.265 & 1.143 & 0.217 & $\begin{array}{l}0.3 \mathrm{PV}(0.5 \% \mathrm{NaOH}+0.1 \% \\
\mathrm{SDS}+2,500 \mathrm{ppm} \text { PHPAM })+0.2 \mathrm{PV} \\
2,500 \mathrm{ppm} \text { buffer }+ \text { chase water }\end{array}$ & 52.9 & 24.2 & 17.284 & 82.716 & 20.4 \\
\hline
\end{tabular}

Table 3 Recovery of oil by ASP flooding with varying concentration of polymer

\begin{tabular}{|c|c|c|c|c|c|c|c|c|c|}
\hline \multirow[t]{2}{*}{$\begin{array}{l}\text { Expt. } \\
\text { No. }\end{array}$} & \multirow[t]{2}{*}{$\begin{array}{l}\text { Porosity } \\
(\%)\end{array}$} & \multicolumn{2}{|c|}{$\begin{array}{l}\text { Permeability, } \\
k \text { (darcy) }\end{array}$} & \multirow[t]{2}{*}{ Design of chemical slug for flooding } & \multirow{2}{*}{$\begin{array}{l}\text { Recovery of oil after } \\
\text { water flooding at } 95 \% \\
\text { water cut ( } \% \text { OOIP) }\end{array}$} & \multirow{2}{*}{$\begin{array}{l}\text { Additional } \\
\text { recovery } \\
(\% \text { OOIP })\end{array}$} & \multicolumn{3}{|c|}{ Saturation $(\%)$} \\
\hline & & $\begin{array}{l}k_{\mathrm{w}} \\
\left(S_{\mathrm{w}}=1\right)\end{array}$ & $\begin{array}{l}k_{\mathrm{o}} \\
\left(S_{\mathrm{wi}}\right)\end{array}$ & & & & $S_{\mathrm{wi}}$ & $S_{\mathrm{oi}}$ & $S_{\text {or }}$ \\
\hline S9 & 37.265 & 1.144 & 0.217 & $\begin{array}{l}0.3 \mathrm{PV}(0.5 \% \mathrm{NaOH}+0.1 \% \\
\mathrm{SDS}+1,500 \mathrm{ppm} \text { PHPAM })+0.2 \mathrm{PV} \\
1,500 \text { ppm buffer }+ \text { chase water }\end{array}$ & 50.02 & 23.69 & 18.519 & 81.482 & 20.49 \\
\hline S10 & 37.265 & 1.145 & 0.217 & $\begin{array}{l}0.3 \mathrm{PV}(0.7 \% \mathrm{NaOH}+0.1 \% \\
\text { SDS + 1,500 PPM PHPAM })+0.2 \mathrm{PV} \\
1,500 \text { PPM buffer }+ \text { chase water }\end{array}$ & 50.42 & 24.08 & 17.284 & 82.716 & 19.630 \\
\hline S11 & 37.265 & 1.144 & 0.218 & $\begin{array}{l}0.3 \mathrm{PV}(1.0 \% \mathrm{NaOH}+0.1 \% \\
\text { SDS + 1,500 PPM PHPA })+0.2 \mathrm{PV} \\
1,500 \text { PPM buffer + chase water }\end{array}$ & 50.54 & 24.91 & 16.231 & 83.951 & 18.772 \\
\hline
\end{tabular}


alkali. The decrease of surface tension of surfactantpolymer solution in the presence of alkali may also be due to charge-shielding mechanism and hydrolysis polymer. This reduced surface tension is one of the most important criteria for enhanced recovery of oil by increasing the capillary number of oil-water system.

\section{Effect of surfactant in ASP flooding}

Surfactants are very effective in reducing the IFT and create emulsion of fluids. Thus, surfactant plays an important role in ASP flooding. Three sets of experiments have been carried out by varying the concentration of surfactant in the injected ASP slug. It has been found that increase in concentration of surfactant increases the additional recovery significantly. The results are shown in Table 4. The main problem of surfactant is that its concentration is depleted quickly by adsorption onto the rock surface. Use of alkali reduces the surfactant depletion rate. Increase in surfactant concentration increases the additional recovery, but the rate of change is higher at lower concentration range.

\section{Optimum design of ASP slug}

A series of experiments on ASP flooding have been performed by varying the composition of ASP slug. The results are shown in Table 5. It has been found that increase in concentration of alkali, surfactant and polymer increases the additional recovery, but after a certain concentration, the increase in recovery is only marginal. Based on the prices of crude oil and the cost of chemicals, the optimum concentration of different chemicals in ASP slug may be varied within a certain concentration range where substantial additional recoveries are obtained. An analysis has been made on the relative cost of the chemical slug injected and the corresponding additional oil recovery as shown in Fig. 6. Based on the present study, the recommended concentration range of alkali, polymer and surfactant used for flooding experiments are $0.7-1.0 \mathrm{wt} \%$,

Table 5 Comparison of flooding performances using ASP slugs of different compositions

\begin{tabular}{lllll}
\hline $\begin{array}{l}\text { Expt. } \\
\text { No. }\end{array}$ & $\begin{array}{l}\text { Concentration } \\
\text { of alkali } \\
(\%)\end{array}$ & $\begin{array}{l}\text { Concentration } \\
\text { of surfactant } \\
(\%)\end{array}$ & $\begin{array}{l}\text { Concentration } \\
\text { of polymer } \\
(\text { ppm })\end{array}$ & $\begin{array}{l}\text { Additional } \\
\text { recovery } \\
(\% \text { OOIP })\end{array}$ \\
\hline 1 & 0.5 & 0.1 & 1,500 & 23.69 \\
2 & 0.5 & 0.1 & 2,000 & 23.9 \\
3 & 0.5 & 0.1 & 2,500 & 24.2 \\
4 & 0.7 & 0.1 & 1,500 & 23.946 \\
5 & 0.7 & 0.1 & 2,000 & 24.446 \\
6 & 0.7 & 0.1 & 2,500 & 24.559 \\
7 & 1 & 0.1 & 1,500 & 24.91 \\
8 & 1 & 0.1 & 2,000 & 25.2 \\
9 & 1 & 0.1 & 2,500 & 25.4 \\
10 & 0.5 & 0.2 & 1,500 & 27.18 \\
11 & 0.5 & 0.2 & 2,000 & 27.3 \\
12 & 0.5 & 0.2 & 2,500 & 27.8 \\
13 & 0.7 & 0.2 & 1,500 & 29.5 \\
14 & 0.7 & 0.2 & 2,000 & 30.7 \\
15 & 0.7 & 0.2 & 2,500 & 31.4 \\
16 & 1 & 0.2 & 1,500 & 30.2 \\
17 & 1 & 0.2 & 2,000 & 30.9 \\
18 & 1 & 0.2 & 2,500 & 31.5 \\
19 & 0.5 & 0.3 & 1,500 & 28.72 \\
20 & 0.5 & 0.3 & 2,000 & 28.95 \\
21 & 0.5 & 0.3 & 2,500 & 29.3 \\
22 & 0.7 & 0.3 & 1,500 & 29.87 \\
23 & 0.7 & 0.3 & 2,000 & 30.1 \\
24 & 0.7 & 0.3 & 2,500 & 30.78 \\
25 & 1 & 0.3 & 1,500 & 30.95 \\
26 & 1 & 0.3 & 2,000 & 31.4 \\
27 & 1 & 0.3 & & 31.98 \\
\hline & & &
\end{tabular}

Table 4 Recovery of oil by ASP flooding with varying concentration of surfactant

\begin{tabular}{|c|c|c|c|c|c|c|c|c|c|}
\hline \multirow[t]{2}{*}{$\begin{array}{l}\text { Expt. } \\
\text { No. }\end{array}$} & \multirow[t]{2}{*}{$\begin{array}{l}\text { Porosity } \\
(\%)\end{array}$} & \multicolumn{2}{|c|}{$\begin{array}{l}\text { Permeability, } \\
k \text { (darcy) }\end{array}$} & \multirow[t]{2}{*}{ Design of chemical slug for flooding } & \multirow{2}{*}{$\begin{array}{l}\text { Recovery of oil after } \\
\text { water flooding at } 95 \% \\
\text { water cut }(\% \text { OOIP) }\end{array}$} & \multirow{2}{*}{$\begin{array}{l}\text { Additional } \\
\text { recovery } \\
(\% \text { OOIP })\end{array}$} & \multicolumn{3}{|c|}{ Saturation $(\%)$} \\
\hline & & $\begin{array}{l}k_{\mathrm{w}} \\
\left(S_{\mathrm{w}}=1\right)\end{array}$ & $\begin{array}{l}k_{\mathrm{o}} \\
\left(S_{\mathrm{wi}}\right)\end{array}$ & & & & $S_{\mathrm{wi}}$ & $S_{\text {oi }}$ & $S_{\text {or }}$ \\
\hline $\mathrm{S} 12$ & 37.265 & 1.144 & 0.217 & $\begin{array}{l}0.3 \mathrm{PV}(0.5 \% \mathrm{NaOH}+0.1 \% \\
\mathrm{SDS}+1,500 \mathrm{ppm} \text { PHPAM })+0.2 \mathrm{PV} \\
1,500 \text { ppm buffer }+ \text { chase water }\end{array}$ & 50.02 & 23.69 & 18.519 & 81.482 & 20.49 \\
\hline S13 & 37.265 & 1.143 & 0.217 & $\begin{array}{l}0.3 \mathrm{PV}(0.5 \% \mathrm{NaOH}+0.2 \% \\
\mathrm{SDS}+1,500 \mathrm{PPM} \mathrm{PHPA})+0.2 \mathrm{PV} \\
1,500 \text { PPM buffer }+ \text { chase water }\end{array}$ & 51.18 & 27.18 & 16.050 & 83.951 & 17.531 \\
\hline S14 & 37.265 & 1.143 & 0.217 & $\begin{array}{l}0.3 \mathrm{PV}(0.5 \% \mathrm{NaOH}+0.3 \% \\
\mathrm{SDS}+1,500 \mathrm{PPM} \text { PHPA })+0.2 \mathrm{PV} \\
1,500 \text { PPM buffer }+ \text { chase water }\end{array}$ & 50.09 & 28.72 & 17.48 & 82.52 & 18.75 \\
\hline
\end{tabular}




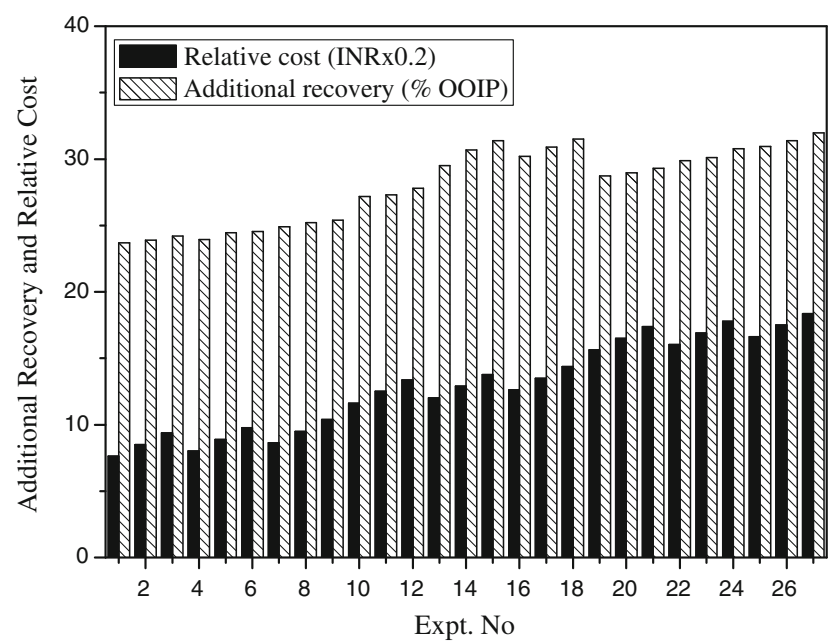

Fig. 6 Comparison of additional oil recovery versus relative cost of chemicals

1,500-2,500 PPM and $0.2 \mathrm{wt} \%$, respectively. However, since the recovery of oil is strongly dependent on the reservoir rock and fluid properties, the concentration range may vary from field to field. Permeability of reservoir rocks plays an important role in selecting the concentration of chemical slug in oil recovery. For low-permeable sand, a good result of oil recovery can be achieved by low concentration of polymer slug. In low-permeable rocks, small amount of polymer (low polymer concentration and slug sizes) effectively improve the mobility control, mainly because of relatively high polymer retention. But in case of high permeable rocks, lower dosages of polymer (high polymer concentration or larger slug sizes) are required to improve effectively the mobility control, mainly because of low polymer retention. Using high polymer concentration in small slug, the oil recovery improvements in high permeable rocks are greater than in low-permeable rocks. Szabo and Corp (1975) reported that when larger volume of fluids were injected, the effect of polymer concentration on oil recovery was not as great. They also reported that on doubling the polymer concentration, the oil recovery is less than a potential increased in recovery at low injected volume.

\section{Conclusion}

In the present study, experiments have been performed to examine the interactions of alkali, surfactant and polymer in ASP slugs. The effects of alkali and surfactant on polymer viscosity leads to the optimum concentration of polymer required for mobility control in the presence of other chemicals. The results on the effects of alkali and polymer on surface tension of polymer solution leads to optimum concentration of surfactant required for reduction of interfacial tension between oil and water. The effectiveness of ASP system on EOR was tested with a series of flooding experiments performed in the sand-pack systems. Recovery efficiencies vary $23-33 \%$ of original oil in place over the conventional water flooding. Several mechanism viz., reduction IFT, emulsification of oil and water, solubilization of interfacial films, wettability reversal, viscosity improvement, etc. are responsible for the EOR. Based on the experimental data and relative cost of different chemicals, concentration range of alkali $(0.7-1.0 \mathrm{wt} \%$,), polymer $(1,500-2,500 \mathrm{ppm})$ and surfactant $(0.2 \mathrm{wt} \%)$ have been recommended for successful ASP flooding.

Acknowledgments We gratefully acknowledge for the financial assistance provided by Council of Scientific and Industrial Research (CSIR, 424/07) and University Grant Commission [F. No. 37-203/ 2009(SR)], New Delhi, to Department of Petroleum Engineering, Indian School of Mines, Dhanbad, India.

Open Access This article is distributed under the terms of the Creative Commons Attribution License which permits any use, distribution, and reproduction in any medium, provided the original author(s) and the source are credited.

\section{References}

Al-Hashim HS, Obiora V, Al-Yousef HY, Fernandez F, Nofal W (1996) Alkaline surfactant polymer formulation for saudi arabian carbonate reservoirs. In: SPE/DOE improved oil recovery symposium, Tulsa, Oklahoma, Paper SPE/DOE 35353

Al-Sahhaf T, Ahmed AS, Elkamel A (2002) Producing ultralow interfacial tension at the oil/water interface. J Petrol Sci Technol 20:773-788

Daoshan L, Shouliang L, Yi L, Demin W (2004) The effect of biosurfactant on the interfacial tension and adsorption loss of surfactant in ASP flooding. Colloids Surf A 244:53-60

Gao S, Li H, Li H (1995) Laboratory investigation of combination of alkali/surfactant/polymer technology for Daqing EOR. SPE Resrv Engg 10:194-197

Gao S, Li H, Yang Z, Pitts MJ, Harry S, Kon W (1996) Alkalinesurfactant-polymer pilot performance of the West Central Saertu, Daqing Oil Field. SPE Reserv Eng 11:181-188

Guo SP (1990) Physical chemical fluid flow in porous media: microscopic mechanism. Science Publication Company, Beijing

Guo SP, Huang YZ (1990) Physical chemistry microscopic seepage flow mechanism. Science Press, Beijing

Guo L, Lim KB, Poduje CM, Daniel M, Gunn JS, Hackett M, Miller SI (1998) Lipid A acylation and bacterial resistance against vertebrate antimicrobial peptides. Cell 95:189-198

Hawkins BF, Taylor KC, Nasr-El-Din HA (1994) Mechanisms of surfactant and polymer enhanced alkaline flooding: application to David Lloydminster and Wainwright Sparky fields. J Can Petrol Technol 13:52-63

Healy RN, Reed RL (1974) Physicochemical aspects of microemulsion flooding. SPE J 14:491-501

Hoff E, Nyström B, Lindman B (2001) Polymer-surfactant interactions in dilute mixtures of a nonionic cellulose derivative and an anionic surfactant. Langmuir 17:28-34

Horváth-Szabó G, Czarnecki J, Masliyah JH (2002) Sandwich structures at oil-water interfaces under alkaline conditions. J Colloid Interface Sci 253:427-434

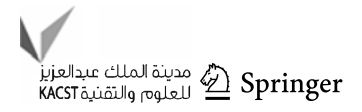


Hou J, Liu Z, Zhang S, Yue X, Yang J (2005) The role of viscoelasticity of alkali/surfactant/polymer solutions in enhanced oil recovery. J Petrol Sci Eng 47:219-235

Johnson CE Jr (1976) Status of caustic and emulsion method. J Petrol Technol 14:85-92

Jun S, Cheng-zhib Y, Zhen-yua Y, Guang-zhia L, Hongb Y, Zhi-jianb D, Yan-qinb L, Zhong-quia Y (2000) surfactant-alkalinepolymer flooding pilot project in non-acidic paraffin oil field in Daqing. In: Asia Pacific oil and gas conference and exhibition, Australia, Paper SPE 64509

Khan MY, Samanta A, Ojha K, Mandal A (2009) Design of alkaline/ surfactant/polymer (ASP) slug and its use in enhanced oil recovery. J Petrol Sci Technol 27:1926-1942

Krumrine PH, Falcone Jr, James S, Campbell, Thomas C (1982) Surfactant flooding 1: the effect of alkaline additives on IFT, surfactant adsorption, and recovery efficiency. SPE J 22:503-513

Krumrine PH, Falcone Jr, James S (1983) Surface, polymer, and alkali interactions in chemical flooding processes. In: International symposium on geothermal chemistry, Denver, paper SPE 11778

Martin FD, Oxley JC (1985) Effect of Various Alkaline Chemicals on Phase Behavior of Surfactant/Brine/Oil Mixtures. In: International symposium on oilfield and geothermal chemistry, Arizona, Paper SPE 13575

Martin FD, Oxley JC, Lim H (1995) Enhanced recovery of a 'J' sand crude oil with a combination of surfactant and alkaline chemicals. In: 60th Annual technical conference and exhibition of the SPE, Las Vegas, NV, SPE 14293

Minatti E, Zanette D (1996) Salt effects on the interaction of poly (ethylene oxide) and sodium dodecyl sulfate measured by conductivity. Colloids Surf A 113:237-246

Nasr-El-Din HA, Hawkins BF, Green KA (1992) Recovery of residual oil using the alkali/surfactant/polymer process: effect of alkali concentration. J Petrol Sci Eng 6:381-401

Nasr-El-Din HA, Green KA, Schramm LL (1994) Recovery of waterflood residual oil using the alkali/surfactant/polymer process: effect of slug size, core length and a polymer chase. Revue de l'Institut Français du Petrole 49:359-377

Nedjhioui M, Moulai-Mostefa N, Morsli A, Bensmaili A (2005) Combiner effect of polymer/surfactant/oil/alkali on physical chemical properties. Desalination 185:543-550

Needham RB, Doe PH (1987) Polymer flooding review. J Petrol Technol 39:1503-1507

Rudin J, Bernard C, Wasan DT (1994) Effect of added surfactant on interfacial tension and spontaneous emulsification in alkali/ acidic oil systems. Ind Eng Chem Res 33:1150-1158

Samanta A, Ojha K, Mandal A (2011) The characterization of natural surfactant and polymer and their use in enhanced recovery of oil. Petrol Sci Technol 29:765-777

Shen PP, Yu JY (2002) Fundamental research on enhanced oil recovery in large scale. Petroleum Industry Publication Company, Beijing

Shen P, Wang J, Yuan S, Zhong T, Jia X (2009) Study of enhancedoil-recovery mechanism of alkali/surfactant/polymer flooding in porous media from experiments. SPE J 14:237-244
Shupe RD (1981) Chemical stability of polyacrylamide polymers. J Petrol Technol 33:1513-1529

Song W, Yang C, Han D, Qu Z, Wang B, Jia W (1995) Alkaline surfactant polymer combination flooding for improving recovery of the oil with high acid value. In: International meeting on petroleum engineering, Beijing, China, SPE 29905-MS

Suksamranchit S, Sirivat A (2007) Influence of ionic strength on complex formation between poly (ethylene oxide) and cationic surfactant and turbulent wall shear stress in aqueous solution. Chem Eng J 128:11-20

Szabo MT, Corp C (1975) Laboratory investigations of factors influencing polymer flood performance. SPR J 15:338-346

Taylor K, Nasr-El-Din HA (1996) The effect of synthetic surfactants on the interfacial behavior of crude oil/alkali/polymer systems. Colloids Surf A 108:49-72

Thomas S, Farouq Ali SM (2001) Micellar flooding and asp-chemical methods for enhanced oil recovery. J Can Petrol Technol 40:48-52

Tong ZS, Yang CZ, Wu GQ, Yuan H, Yu L, Tian G (1998) A study of microscopic flooding mechanism of surfactant/alkali/polymer. In: SPE/DOE improved oil recovery symposium, Tulsa, Oklahoma, Paper SPE 39662

Walters K, Jones DM (1989) The extensional viscosity behavior of polymeric liquids of use in EOR. In: SPE international symposium on oilfield chemistry, Houston, Texas, Paper SPE 18497-MS

Wanchao S, Chengzhi Y, Dakuang H, Zhijian Q, Baoyu W, Province S. Wenluo J (1995) Alkaline-surfactant-polymer combination flooding for improving recovery of the oil with high acid value. In: International meeting on petroleum engineering, Beijing, China, Paper SPE 29905

Wang J, Yuan S, Shen P, Zhong T, Jia X (2007) Understanding of fluid flow mechanism in porous media of EOR by ASP flooding from physical modeling. In: International petroleum technology conference, Dubai, Paper SPE 11257

Wang Y, Zhao F, Baojun B, Zhang J, Xiang W, Li X, Zhou W (2010). Optimized surfactant IFT and polymer viscosity for surfactantpolymer flooding in heterogeneous formations. In: SPE improved oil recovery symposium, Tulsa, Oklahoma, USA, Paper SPE 127391-MS

Wang B, Wu T, Li Y, Sun D, Yang M, Gao Y, Lu F, Li X (2011) The effects of oil displacement agents on the stability of water produced from ASP (alkaline/surfactant/polymer) flooding. Colloids Surf A 379:121-126

Zerpa LE, Queipo NV, Pintos S, Salager JL (2005) An optimization methodology of alkaline-surfactant-polymer flooding processes using field scale numerical simulation and multiple surrogates. J Petrol Sci Eng 47:197-208

Zhang L, Xiao H, Zhang H, Xu L, Zhang D (2007) Optimal design of a novel oil-water separator for raw oil produced from ASP flooding. J Petrol Sci Eng 59:213-218 